\title{
Evaluation of Different Insecticides against Onion Thrips in Onion Seed Production
}

\author{
M. K. Pathak ${ }^{1}$, M. K. Pandey ${ }^{1 *}$, R. C. Gupta ${ }^{1}$ and P. K. Gupta ${ }^{2}$ \\ ${ }^{1}$ National Horticultural Research and Development Foundation, (NHRDF) Regional Research \\ Station, Chitegaon Phata, Nashik (Maharashtra), India \\ ${ }^{2}$ National Horticultural Research and Development Foundation, Head office, NHRDF, \\ Janakpuri, New Delhi, India \\ *Corresponding author
}

\section{A B S T R A C T}

\begin{tabular}{|l|}
\hline Ke y w or d s \\
Onion, Seed crop, Thrips \\
tabaci, insecticides
\end{tabular}

\begin{abstract}
A field experiments was conducted at NHRDF, Regional Research Station, Chitegaon, Nashik in three consecutive years during rabi 2013-14, 2014-15 and 2015-16 on onion variety NHRDF Red-2 for the management of onion thrips through basal application and spray of different insecticides. The soil application of the treatments was given before planting and spray was started at 10 DAP after the appearance of thrips and subsequently sprays were given at ten days interval. The results showed that, significantly lowest mean thrips population (17.21 nymphs/plant) and highest seed yield (4.91q/ha) were recorded in basal application of Chlorantraniliprole $0.4 \%$ @ 10Kg/ha and spray of Fipronil @ 0.1\%, Carbosulfan@0.2\%,Profenofos@0.1\% and Spinosad @ 0.03\%. The highest cost benefit ratio $(1: 4.19)$ was also recorded in the same treatment.
\end{abstract}

\section{Introduction}

Onion is a cross pollinated crop and more than $90 \%$ pollination is done by honey bee. Thrips tabaci is the most important insect attacking onion seed production crop and also spreading viral diseases. Onion thrips (Thrips tabaci Lindeman) is the most important pest of onion (Allium cepa L.) and cause significant yield losses globly (Lewis, 1997). The nymphs and adult of onion thrips feed leaves by piercing and rasping the leaf tissues and causes lengthwise, silvery stippling or blotching on the onion leaves, resulting in the loss of chlorophyll and reduced photosynthetic efficiency (Boateng et al., 2014). Onion is an important export oriented vegetable crop among the cultivated Alliums in India. It is grown in rabi, kharif and late kharif season in India with the maximum area under cultivation covered during rabi season. India is the second largest onion producing country in the world.

Thrips (Thrips tabaci Lindeman) is a regular and potential pest of onion and cause considerable loss as high as $90 \%$ in quality and yield (Gupta et al., 1984). Failure to control this pest by timely and effective means causes considerable damage and results in immense economic loss by remarkably reducing yield (Anonymous, 2000; Juan, 
2002). Confidor 200 SL (Imidachlorprid), Tracer 240 SC (Spinosad) and Thiodan 35SC were found effective against onion thrips in Pakistan (Ullah et al., 2010).

To find out the suitable management of thrips and avoid the losses caused by thrips in onion seed crop, The field experiment was conducted at National Horticultural Research and Development Foundation, Regional Research Station Chitegaon, Nashik during three consecutive years in rabi 2013-14, 201415 and 2015-16 on onion variety NHRDF Red-2 through basal application and spray of different insecticides for thrips management.

\section{Materials and Methods}

The field experiment was conducted at National Horticultural Research and Development Foundation, Regional Research Station, Chitegaon, Nashik during rabi, 201314, 2014-15 and 2015-16 seasons. Bulbs of onion variety NHRDF Red-2 were planted in a bed size of $5.0 \mathrm{~m} \times 3.0 \mathrm{~m}$ at $45 \mathrm{~cm} \mathrm{X} 30 \mathrm{~cm}$ spacing. Randomized Block Design with 3 replication was followed. The treatments evaluated were T1 (Basal application of Phorate 10G@15Kg/ha + Spray of Fipronil $@ 0.1 \%, \quad$ Carbosufan @ $0.2 \%$, Profenofos@0.1\% and Spinosad @0.03\%, T2 (Basal application of Cartaphydrochloride $4.0 \% @ 25 \mathrm{Kg} / \mathrm{ha}+$ Spray of Fipronil @0.1\%, Carbosulfan@0.2\%, Profenofos@0.1\% and Spinosad @0.03\%, T3(Basal application of Carbofuran 3G@30kg/ha + spray of (Fipronil @0.1\%, Carbosulfan @0.2\%, Profenofos@0.1\% and spinosad @0.03\%, T4 (Soil application of Fipronil 0.3G@25Kg/ha + spray of (Fipronil @0.1\%, Carbosulfan @0.2\%, Profenofos@0.1\% and Spinosad $@ 0.03 \%, \quad \mathrm{~T} 5$ (Basal application of Imidachlorprid 0.5G @20kg/ha + spray of (Fipronil@0.1\%, Carbosulfan @0.2\%, Profenofos@0.1\% and Spinosad @0.03\%, T6(Basal application of Chlorantraniliprole
0.4\% @ 10Kg/ha + Spray of (Fipronil@0.1\%, Carbosulfan@0.2\%,Profenofos@0.1\% and Spinosad @0.03\%) and T7 (control). The soil application of treatments were given before planting and spray was started at 10 DAP after the appearance of the thrips and a total of 9 sprays were given at 10 days interval. The insecticide sprays were given in evening time to avoid on dry toxic effect honey bee. All other agronomical practices were performed as per need uniformly in all the treatments. The picking of umbel was started after attaining the maturity of seed and a total 4-5 pickings were done during cropping period. The data on thrips (Nymph) population were counted at the stalk as well as umbel in 10 plants marked randomly selected plants in each treatment at 10 days interval before each spray.

\section{Results and Discussion}

The data presented in table 1 revealed that thrips population at different stages of growth of crop and seed yield were influenced significantly due to different treatments. The thrips population did not follow any definite trend at different stages of growth, a mixed trend of increasing and decreasing the thrips population was observed. Significantly lowest mean thrips population (17.21 nymphs/plant) were recorded in T6 (Basal application of Chlorantraniliprole 0.4\% @ 10Kg/ha + Foliar spray of Fipronil @ 0.1\%, Carbosulfan @ $0.2 \%$, Profenofos @ 0.1\% and Spinosad @ $0.03 \%)$. The highest seed yield (4091 q/ha) and $\mathrm{C}$ : $\mathrm{B}$ ratio (1:4.19) was also recorded in treatment $\mathrm{T} 6$.

Pandey et al., (2013) recorded that lowest thrips population and highest bulb yield with highest cost benefit ratio by applying fipronil. The other workers also reported that fipronil and imidachlorprid reduced the thrips damage severity and increased the onion bulb yield (Ullah et al., 2010; Gachu et al., 2012). 
Table.1 Evaluation of different insecticides against thrips on onion seed production at NHRDF, RRS, Nashik (pooled data of rabi 2013-14, 2014-15, 2015-16)

\begin{tabular}{|c|c|c|c|c|c|c|c|c|c|c|c|c|}
\hline & \multicolumn{9}{|c|}{ Thrips Population (nymphs/plant) } & \multirow[b]{2}{*}{$\begin{array}{l}\text { Overall } \\
\text { mean } \\
\text { thrips } \\
\text { population }\end{array}$} & \multirow[b]{2}{*}{$\begin{array}{l}\text { Seed } \\
\text { yield }(q / h a)\end{array}$} & \multirow[b]{2}{*}{$\begin{array}{l}\text { C: B } \\
\text { Ratio }\end{array}$} \\
\hline Treatments & 10DAP & 20DAP & 30DAP & 40DAP & 50DAP & 60DAP & 70DAP & 80DAP & 90DAP & & & \\
\hline T1 & 27.42 & 20.33 & 18.62 & 16.64 & 28.54 & 26.22 & 32.69 & 23.62 & 20.49 & 20.70 & 4.13 & $1: 2.68$ \\
\hline T2 & 26.36 & 18.60 & 23.91 & 15.71 & 30.14 & 24.11 & 33.47 & 23.87 & 19.26 & 20.94 & 4.17 & $1: 2.74$ \\
\hline T3 & 25.47 & 22.69 & 27.22 & 16.03 & 31.13 & 26.29 & 34.40 & 23.27 & 17.29 & 21.55 & 4.20 & $1: 2.73$ \\
\hline T4 & 23.67 & 19.16 & 15.29 & 15.20 & 31.91 & 24.60 & 31.24 & 22.56 & 23.67 & 20.31 & 4.29 & $1: 2.95$ \\
\hline $\mathrm{T5}$ & 27.40 & 18.07 & 20.84 & 13.73 & 31.22 & 22.58 & 29.53 & 21.16 & 16.21 & 19.33 & 4.53 & $1: 3.48$ \\
\hline T6 & 24.47 & 16.27 & 21.82 & 13.69 & 26.7 & 19.38 & 23.58 & 16.11 & 11.93 & 17.21 & 4.91 & $1: 4.19$ \\
\hline T7 & 49.93 & 53.89 & 80.39 & 42.20 & 66.60 & 59.60 & 65.34 & 35.91 & 48.66 & 44.75 & 2.83 & - \\
\hline S.Em \pm & 1.98 & 1.52 & 2.66 & 1.42 & 2.97 & 1.78 & 3.24 & 1.38 & 1.52 & 0.73 & 0.09 & - \\
\hline CD at $5 \%$ & 4.01 & 3.09 & 5.39 & 2.89 & 6.02 & 3.6 & 6.57 & 2.8 & 3.09 & 1.48 & 0.18 & - \\
\hline
\end{tabular}

The finding of present study are in conformity with the earlier results obtained by Patel et al., 2001 and Noor, 2001 who found Profenophos was may effective against many sap feeding insects such as onion thrips and Chilli thrips.

Similarly, Lazano and kilchher (1998) reported that Spinosad may also be used for controlling thrips under field conditions.

The farmers are extensively and successfully using contact and synthetic insecticides and also synthetic pyrethroides for controlling the pest.

However, repeated application of same group of chemicals is not a desirable practice as this could lead to undesirable resistance problems.

Based on 3 years study on onion variety NHRDF Red-2, it could be concluded that the basal application of Chlorantraniliprole $0.4 \%$ (a) $10 \mathrm{~kg} / \mathrm{ha}$ and subsequently sequential sprays of Fipronil @ 0.1\%, Carbosulfan @ $0.2 \%$, Profenofos @ 0.1\% and Spinosad @ $0.03 \%$ at 10 days interval is effective for managing of thrips and increasing the yield of onion seed with highest cost benefit ratio (1:4.19) at Nashik, Maharashtra.

\section{References}

Adesiun, A. A. and Ibrahim, N.D., (2010). Effect of transplanting dates and insecticide frequency in the control of Thrips tabaci Lindeman (Thysanoptera: Thripidae) on onion (Allium cepa L.) in Sokoto, Nigeria. J.Agric.Sci.., 2(2):239-249.

Altaf, H., Muhammad, S., Juma. K., Mohammad, I. and Saifulla, K. (1999). Effect of nonchemical methods and botanical insecticides on onion thrips. Thrips tabaci L. In onion crop in Balochistan. Sarhad J. Agric., 15:619-624.

Anonymous (2000). Annual Report: National Research Centre for onion and Garlic. pp. 63-64.

Boateng C O, Schwartz H F, Heavey M J and Otto $\mathrm{K}$ (2014). Evaluation of onion germplasm for resistance to Iris Yellow Spot Virus (Iris yellow spot virus) and onion thrips, Thrips tabaci, Southwestern Entomologist 39: 23760.

Chandrakar, H.K. and Srivastva, S.K. (2001). Efficacy and economics of some insecticides to thrips, Caliothrips Indicus in Lathyrus. Environ. \& Ecol., 19(1):241-243.

Gachu S M, Muthomi J W, Narla R D, Nderitu JH, Olubayo F M and Waga JM. (2012). Management of thrips (Thrips tabaci) in bulb onion by using of vegetable inter 
crops. International Journal of Agriscience 2 (5):393-402.

Gupta, R.P. and Sharma, R.C. (1998). Effect of new insecticides/ biopesticides on control of onion thrips. NHRDF News letter 18(4): 5-7.

Gupta, R.P., Srivastva, V.K., Bhardwaj, B.S. and Pandey U.B. (1984). Chemical control of thrips tabaci L. infesting onion crop. J.Ent.Res. 8(2)196-198.

Juan, Anciso (2002). Onion world, 18(3): 10.

Krishna Kumar, N.K., Krishna Moorthy, P.N., Kalleshwaraswamy, C.M. and Ranganath, H.R., (2008). Management of thrips (Thrips tabaci Lindeman) on organically raised rose onion. Pest management in Horticultural Ecosystems, 14(2): 1128-132.

Lazano, D., and Kilcchher, G. (1998). How to choose oil to safely kill bugs. The press democrat. June 21:1.

Lewis (1997).Pest thrips in perspective-In: Lewis, T. (ed): Thrips as crop pest $C A B$ international, Wallingford, UK: 1-14.

Mandi, N. and Senapati, A.K. (2009), Integration of chemical botanical and microbial insecticides for control of thrips, Scirtothrips dorsalis Hood infesting chilli. J. Plant Prot. Sci., 1: 92-95.

Mohamed AS. (2006). Evaluation of the insecticide eureka (lambdacyhalothrin) 5EC for the control of onion thrips (Thrips tabaci) on onion. http.//agris.fao.org/aos/records/SD2011000 054.pp.66-70.

Nault B A, Hsu C and Hoepting C. (2013). Consequences of co-applying insecticides and fungicides for managing Thrips tabaci (Thysanoptera: Thripidae) on onion. Pest management science 69:841-9.

Noor, A. (2001). Field evaluation of newer insecticides against sucking pests infesting Chilli in western Rajasthan In: Bhardwaj, S.S, Saxena, R.C. and Swaminathan, R (eds). Proc.conf: Plant protection. New Horizons in Millennium Feb.23-25, 2001, Udaipur, P.33.

Pandey S, Mishra RK, Singh AK, Singh SK (2012). Studies on entomopathogenic fungus for management of onion thrips to produce quality onion. Biopestic. Int. 8: 2, 165-167.

Pandey Sujay, Singh B K and Gupta R P. (2013). Effect of neem based botanicals, chemical and bio-insecticides for the management of thrips in onion. Indian Journal of agriculture Research 47(6): 545-8.

Patel, M.G., Chavda, A.J., Sisodia, D.B. and Patel, J.R (2001). Bio-efficacy of new molecules in comparison to conventional insecticides against onion thrips in middle Gujrat. In: Bhartdwaj S.S. SAXENA, R.C. and Swaminathan, R. (eds.) Proc.Nat.Conf: Plant Protection. New Horizons in Millennium Feb.23-25, 2001, Udaipur, P.30.

Shiberu Tadele and Negeri Mulugeta (2014). Evaluation of insecticides and botanicals against onion thrips. Thrips tabaci (L) (Thysanoptera: Thripidae). Entomology and Applied Science 1 (2): 26-30.

Shitole, D.M., Shanker, G. and Mithyantha, M.S. (2002). Evolution of certain new pesticides against thrips (T.tabaci). Pestol., 26(2): 4952.

Ullah Farman, Mulk Maraj-ul, Farid Abid, Saeed Mohamad Qasid and Sattar Shahid. (2010). Population dynamics and chemical control of onion thrips (Thrips tabaci Lindemann). Pakistan Journal of Zoology 42(4): 401-6.

Verma SC, Meena T, Kanwar, HS. Efficacy of insecticides against onion thrips, Thrips tabaci Lindemanon garlic under MIDHHILL condition of Himachal Pradesh. Journal of insect Science. 2012 (2): 76-78.

\section{How to cite this article:}

Pathak M. K., M. K. Pandey, R. C. Gupta and Gupta P. K. 2018. Evaluation of Different Insecticides against Onion Thrips in Onion Seed Production. Int.J.Curr.Microbiol.App.Sci. 7(07): 4204-4207. doi: https://doi.org/10.20546/ijcmas.2018.707.491 